\title{
On the asymmetric relationship between stock market development, energy efficiency and environmental quality: A nonlinear analysis
}

\author{
Mayssa MHADHBI ${ }^{1}$, Mohamed Imen GALLALI ${ }^{2}$, Stephane GOUTTE ${ }^{3}$, and
} Khaled GUESMI ${ }^{4}$

\author{
${ }^{1}$ University Paris-Saclay, CEMOTEV,France ; CRECC - Paris School of business; \\ RIM-RAF, ESCT - Tunis \\ ${ }^{2}$ Ecole Superieure de Commerce de Tunis, RIM-RAF, Manouba University, \\ Tunisia \\ ${ }^{3}$ Universite Paris-Saclay, CEMOTEV, France \\ ${ }^{4}$ Center of Research for Energy and Climate Change (CRECC), Paris School of \\ Business, France
}

March 15, 2021

\begin{abstract}
It has been widely documented in the literature that financial development drives up the impact of $\mathrm{CO}_{2}$ emissions through increases in real economic activities and the consumption of polluting fossil fuel energy. However, when dealing with stock market development, such upward effects on economic growth, energy efficiency, and carbon emissions seems to give away to a positive impact especially in emerging markets. This paper contributes to this debate by exploring both the symmetric and asymmetric responses of $\mathrm{CO}_{2}$ emission to changes in stock market development indicators. In particular, using both the panel linear and nonlinear ARDL, our results demonstrate the asymmetric effects of stock market development indicators on carbon emissions in the context of emerging markets. In particular, the long-run elasticities results suggest that positive and negative shocks on stock market indicator decreases environmental quality by increasing carbon emissions. Based on these empirical findings, this study offer some crucial policy implications.
\end{abstract}

Keywords: Stock market development; Carbon emissions; Energy efficiency; Asymmetric relationship; NARDL model;

JEL Classification: Q 43; G28; E44; F64 


\section{Introduction}

It has been variously argued that the rapidly changing climate and environmental degradation is one of the greatest problems facing humanity in recent times. As stated in its 2030 Agenda for Sustainable Development, the United Nations re-demonstrates its commitment and determination to protect the planet from degradation, including through sustainable consumption and production through a sustainable management of the earth's scarce natural resources and taking urgent action on climate change, with the aim of supporting the needs of both the present and future generations (U.N. 2015). Prominent among other factors, carbon dioxide $\left(\mathrm{CO}_{2}\right)$ emissions and air pollution stemming from the manufacture and the burning of fossil fuel have been identified as a leading causes of climate change. Consequently, given the damaging effects of climate change on the process of economic growth and financial market development, a growing level of research has been dedicated towards sustainable economic growth and financial market development through reduction in carbon dioxide emission by researchers, financiers, and policymakers.

For instance, an increasing number of empirical studies have investigated the relationship between stock market development, economic growth, and environmental quality for different countries. Results from these studies demonstrate that the development of stock market may exert two opposing impacts on environmental quality across different countries and regions (see e.g. Paramati et al. 2017; Zafar et al. 2019; Zhao and Yang, 2020). Furthermore, another strand of literature has incorporated the roles of conventional and renewable energy consumption in the relationship between stock market development and environmental quality. This trend in literature has been attributed to the perceived role of the current energy mix which is dominated by fossil fuel energy consumption. Moreover, the financial markets in advanced countries are well developed with market participants and policymakers bounded by the strict regulations that control the levele of carbon emissions in listed companies by adopting energy efficiency technologies and enhancing the use of green energies in place of conventional energies in order to improve environmental quality.

However, to our best knowledge, there is paucity of empirical studies on the impacts of financial markets on environmental quality across emerging markets. Relative to developed markets, there are remarkable peculiarities that suggest that the effects of stock markets on environmental quality may be asymmetric due to the differences in the level of stock market development between developed and emerging markets. First, emerging markets are defined by market volatility due to political instability, external price movements, as well as supply and demand shocks. These factors exposes investors to risk fluctuation in market performance as well as exchange rates. Further, emerging markets are attractive to foreign investors because of high returns on investment. They are characterized by higher rates of GDP growth, stock prices, and returns for investors due to their competitive advantage notably, in the export of commodities. Second, in emerging countries, the use of conventional fossil fuel energy remains widespread in the production of most goods and services, making it crucial to explore the determinants of energy demand. More so, the increasing level of economic activities in emerging markets entails rapid increase in energy demand.

Thirdly, given that stock market development is multi-dimensional and has been variously captured using a set of competing indicators, the perceived asymmetry across the effects of these indicators on environmental quality has also attracted the attention of researchers and policy makers (see e.g. Alex et al 2020). Also, many studies have also investigated the non-linearity in the relationship between stock market indicators, energy prices and environmental quality (see e.g. Xu et al 2019; Tuna and Tuna 2019; Balcilar et al 2019; Chekir et al 2020; Escobari and Sharma 2020). Regarding the non-linear effects of financial market development on environmental quality, empirical results have been diverse across different countries. For instance, recent findings from Yue et al (2019) demonstrate that financial development has significant nonlinear effects on energy consumption in transitional countries. In the literature, most studies have investigated the link between financial development and energy demand using the composite stock market development index. However, just a very few studies have explored the asymmetric impact of stock market development on carbon missions especially in emerging markets. In this study, we examined both linear and nonlinear relationship between the development of stock market and environmental quality. 


\subsection{Stock market - environmental quality nexus:}

Energy consumption remains a key factor that has led to the recent increases in the level of carbon emissions. Also, stock market development has been indirectly linked to the substantial increase in the consumption of energy in recent times. This is because the activities of stock markets have impact on the quality of the environmental at least in two different ways. On one hand, some studies have highlighted the positive impact of stock market indicators on $\mathrm{CO}_{2}$ emission. First, stock market development provides new sources of funds, it represents another way through which equity finance can be raised and this can help companies grow and raise further development. In addition, the stock market is considered critical to economic development by giving companies the ability to rapidly access capital from the public which leads to increase in economic activities such as manufacturing activities. Second, economic growth is strongly related to energy consumption, with the growth of business and production activities leading to the consumption of more energy which promotes the increase in carbon emissions (Sadorsky, 2011).

On the other hand, by enforcing strict regulations on listed companies, financial markets have the potential to facilitate an increase in energy efficiency which strengthens environmental quality by reducing carbon emissions. Previously, conventional energy played a primary role in energy consumption for production, and this use has many disadvantages. This is because primary or conventional energy sources come essentially from fossil fuel. Put differently, this is a non-renewable energy source as it comes from sources that will run out or will not be replenished within a lifetime. Secondly, the use of conventional energy sources can affect environmental quality negatively by increasing carbon emission. However, despite this fact, stock market has the potential to enforce environmental quality by making strong regulations on listed companies (Lanoie et al. 1998).

Furthermore, such regulation may be enforced to control listed companies and to limit their level of conventional energy demand. Consequently, this regulation tends to increase environmental quality by promoting the adoption of energy efficient and greener technologies by listed companies. However, renewable energies can play an important role in reducing carbon emission. In this case, the stock market represents an important source of financing for green investment, making fund more available for clean and renewable energy projects. Taken together, these roles of the financial markets help economies to limit the increasing demand for fossil-fuel energy sources and limit $\mathrm{CO}_{2}$ emissions, which are associated with environmental quality. The main concern of this study relates to investigating both the symmetric and asymmetric relationship between stock market development, energy consumption, and environmental quality. Thus, this paper aims to contribute to the understanding of the role of stock markets, energy consumption in environmental quality.

\section{Literature review}

Given that energy consumption plays a key role in determining the level of environmental quality, through the role of energy use in carbon emission. This section summaries the existing empirical findings and methodologies used in the literature on how economic growth impacts on carbon emission via energy consumption. On the other hand, we focus on the role of the stock market development in energy use and carbon emissions. First, many studies have concentrated on the relationship between energy consumption and economic growth. Most of these studies have identified the causal relationship between energy consumption and economic growth. These studies were driven by the fact that energy resources represent a key factor of production in the sense that energy consumption was considered as a factor influencing economic growth by increasing production (Georgescu-Roegen, 1975).

Fundamentally, some studies have demonstrated that energy consumption is a result of macroeconomic conditions (see e.g. Lermit and Jollands, 2001). Even more, Bartleet and Gounder (2010) provide an overview of the links between energy consumption and real GDP using trivariate and multivariate models. Their findings supports the presence of causal relationship between energy consumption and real GDP. They also show a long-run causality when energy consumption is the dependent variable and a short run causality from real GDP to total energy consumption. This provides further support that economic growth causes demand for energy. Previous researches who focused on environmental quality have investigated the linkages among financial development, 
economic growth, energy use, and carbon emission. Most of them have relied on Foreign Direct Investment (FDI) as proxy for domestic financial market development because it is widely assumed that economies with high level of financial market development has the potential of attracting more FDI (see e.g. Abbasi and Riaz, 2016).

Using different methods of estimation, many studies have explored the link between FDI and environmental quality (see e.g. Seker et al, 2015; Haug and Ucal, 2019; Demena and Afesorgbor, 2019). Particularly, Muhammad and Shan (2019) have demonstrated that FDI, energy consumption, and carbon emissions play a crucial role in the growth of economic activities in Asian countries. Following this findings, they recommend the use of new policies to promote the transition to clean energy use in order to alleviate environmental pressure from fossil fuel based energy consumption. Moreover, apart from economic growth, financial markets development indexes are among key variables of interest in energy studies. Financial market development can affect energy demand positively, which decreases indirectly environmental quality by increasing $\mathrm{CO}_{2}$ emissions. While the development of stock market can affect environmental quality in this way, empirical evidence suggest that stock market development can also improve energy efficiency by enhancing the introduction of energy-saving technologies and financing clean energy projects (see e.g. Paramati et al, 2017, Zfar et al 2019 Zhao and Yang 2020).

It is widely held that financial development significantly affects energy consumption. However, whereas many studies have focused on the links between environmental quality and economic development, much attention has not been given to the links between financial development energy demand. Economic theory and many empirical studies have highlighted the importance of capital markets as a major drive of economic development. In a bid to strengthen pollution control, Lanoie et al. (1998) argue that policymakers enforce actions for investors to evaluate and compare companies with regards to their environmental performance. The stock market is considered as an excellent economic indicator of a country's real economic activities; it reflects the financial situation of listed companies and plays a vital role in economic growth. The development of stock market has the potential to attract more investors and expand their business activities (Sadorsky, 2010).

However, despite the clear theoretical links between stock market development and energy demand, the impact of financial development on energy use has attracted a growing attention, especially in recent decades. Whereas most of these studies have concentrated on developed markets, only a few studies have investigated the links between stock market development and energy consumption in emerging economies. The development of stock market activity induces economic growth and this impacts the demand for energy because economic growth requires more energy consumption. In particular, Sadorsky (2010) using key stock market indicators found that the development of stock market has a significant positive impact on energy consumption in 22 emerging economies. In a similar study, Sadorsky (2011) examined the impact of financial development on energy consumption for nine countries of Eastern and central Europe frontier economies using panel Generalized Method of Moments (GMM). The results suggest that only stock market turnover has a positive and significant impact on energy consumption.

A growing stream of empirical studies have focused on the role of stock market development in environmental quality. For instance, Shahbaz et al. (2013) investigated the linkage between economic growth, energy demand, financial development, and carbon emissions in Indonesia, using the ARDL method. The results of this study indicated that economic growth decreases carbon emission while financial development decreases it. Moreover, the result obtained by the VECM test found that exists bidirectional causality between economic growth and CO2 emission; likewise, financial development granger causes carbon emission, knowing that financial development was proxied by real domestic credit to private sector per capita. Chang (2015) investigated nonlinear effects of financial development and income on energy demand using a panel threshold approach, he finds that energy use increases with economic growth in emerging market and developing economies while energy consumption increases with economic growth at a turning point which the economy achieves a threshold level of income in advanced economies. 
Furthermore, in a more recent empirical study, Ulusoy and Demiralay (2016) focused on the impact of stock market developments on oil and electricity demand of OECD member countries using the Partial Adjustment Model (PAM) the results suggest that stock market development indicators affect positively and significantly both oil and electricity consumption. Lin and Benjamin (2018) have also examined the interactions between economic growth, energy consumption and foreign direct investment using a panel dynamic ordinary least squares model, the result reveals that there exist a bi-directional causal relationship between economic growth and energy consumption in a global panel. In the same vein, Gaies et al (2019) examined the link between financial development and energy consumption in several MENA countries, the results of linear and non-linear dynamic panel models indicate a non-linear and inverted U-shaped relationship between financial development and energy demand. This study supports the view that energy consumption is initially positively related to financial development and it declines at a turning point of financial development.

Moreover, Yue et al (2019) demonstrate that the development of stock market leads to a decrease energy consumption especially in developed stock markets due to decreasing financing costs for public and private sectors which helps to introduce advanced energy-saving technologies and improve energy efficiencies. Moreover, Apergis and Gangopadhyay (2020) have tested the asymmetric relationship between pollution and energy consumption in Vietnam using the NARDL method. Recent studies have focused on the role of stock market development on renewable energy use. Strong stock markets where investors enhance listed companies to use renewable energy in order to maintain energy efficiency and increase environmental quality Paramati et al (2017). Using Auto-Regressive Distributed Lag ARDL method, Ramzi et al (2019) have examined the relationship between two types of renewable energy consumption, stock market development and economic growth in Iran, the results show that stock market value impacts, in the long-run, renewable energies consumption.

In addition, Fan and Hao (2019) have found a causal relationship between renewable energy consumption, economic growth, and foreign direct investment. Contrariwise, Tuna and Tuna (2019) have found that there is a non-causal relationship between economic growth and non-renewable energy consumption for major countries of ASEAN-5 countries. Ziaei (2015) investigated the effects of credit market and stock market shocks on energy consumption and $\mathrm{CO}_{2}$ emissions in European, East Asian and Oceania countries. The result indicates that stock variables have an important effect on energy consumption in countries with developing asset markets. Begum et al (2015) find that per capita energy consumption and per capita GDP have a long-term positive effect on per capita carbon emissions. Many studies have highlighted the role of renewable energy use in the maintenance of environmental quality. (Salim and Rafiq, 2012) have found that renewable energy consumption is determined by both income and carbon emissions in a number of emerging market economies. In addition, the finding of (Bahattacharya et al, 2016) shows that renewable energy use has a positive and significant effect on economic growth in 38 of major economies.

Stock market development is taking place between the most vital sources of financing clean energy project, which lead to a higher level of investment in clean energy project (Sadorsky 2010, 2012; Alam et al., 2015; Paramati et al 2016; Paramati et al 2017). Several studies suggest that stock market development play a crucial role in increasing environmental quality by enhancing investment in a clean energy project. The finding of (Paramati et al, 2016) have underlying that both FDI and stock market development have a significant and positive impact on clean energy use in emerging market economies. Considering the fluctuating and highly volatile behavior of a financial component as a stock market, two types of approach have noticed in the literature dedicated to the relationship between stock market and carbon emission. The first approach is a linear method according to which the relationship between these two components would be symmetrical. The second approach is a non-linear approach, which considers that the increases and decreases of the stock market variable would have rather asymmetrical implications on $\mathrm{CO}_{2}$ emission. 
Lastly, many studies have explored the asymmetric relationship between stock market, energy price and economic growth using various econometric methods. Several studies have investigated the link between the oil price shocks and various economic variables using nonlinear approaches Zhang (2008); Nusair (2016). Recently, Khan et al (2020) have examined the asymmetric effect of energy use and economic growth on environmental quality using NARDL technique; the findings ascertain the asymmetric effect between positive shocks to environmental quality and energy consumption. Moreover, many studies have explored the asymmetric relationship between energy use and stock market and environmental variables. Apergis and Gang (2020) tested the presence of asymmetric relationships between pollution, energy use and oil prices in Vietnam using a Non-linear Auto-Regressive Distributed Lage (NARDL) model. The result suggest that In addition, using the same method, Qamruzzaman and Jianguo (2020) confirmed the presence of an asymmetric relationship between financial development, foreign capital flows, trade openness, and renewable energy consumption.

\section{Data and methodology}

\subsection{Data}

In this study, we use a panel data comprising 19 emerging markets. In particular, the selected emerging markets includes Brazil, Chile, China, Colombia, Czech Republic, Greece, Hungary, India, Indonesia, Korea, Malaysia, Mexico, Pakistan, Peru, Philippines, Poland, South Africa, Thailand, and Turkey. Our dataset is a balanced yearly panel data that covers the period from 1994 to 2014. Following the usual procedure, we converted all variables into their natural logarithmic equivalents before proceeding with the estimation. Consequently, this enables us to estimate coefficients that are interpreted as the elasticities following numerous previous studies (Battacharya et al 2017, Paramati et al 2016; 2018).

In Table 1, we present the definition of all the variables used in this study as well as their sources while Table 2 displays the descriptive statistics of all the variables for each emerging market economy for the period from 1995 to 2014. From Table 2, we can deduce that there is a significant difference in per capita carbon emissions across these economies. In particular, Czech Republic has the highest carbo emission of about 11.24 metric tons followed by Korea with about 9.99 metric tons are the two most carbon emitting economies while Philippines with about 0.89 metric tons followed by Pakistan 0.817 metric tons are the least. Further, energy intensity appear to be highest in South Africa $(10.15 \mathrm{MJ} / \$)$ and in China $(9.97 \mathrm{MJ} / \$)$, whereas the lowest is in Colombia $(2.92 \mathrm{MJ} / \$)$ and in Peru $(2.74 \mathrm{MJ} / \$)$. The Highest per capita market capitalization are achieved in China $(2.49 \mathrm{e}+12 \$)$ and India $(9.93 \mathrm{e}+11 \$)$, while the lowest stock market capitalization are in Czech Republic $(2.73 \mathrm{e}+10 \$)$ and Hungary $(2.63 \mathrm{e}+10 \$)$. Likewise, Korea $(19393.35 \$)$, Greece $(4697.7 \$)$ and Turkey $(2801.777 \$)$.

Table 1: Variables definitions

\begin{tabular}{llll}
\hline & Variables & Definition & Sources \\
\hline Environmental quality & CO2 emission per capita & $\begin{array}{l}\text { The per capita metric ton } \\
\text { carbon dioxide emission }\end{array}$ & WDI \\
\hline $\begin{array}{l}\text { Stock market development } \\
\text { indicators }\end{array}$ & $\begin{array}{l}\text { Stock market capitalization } \\
\text { per capita }\end{array}$ & $\begin{array}{l}\text { Total market capitalization } \\
\text { of listed domestic compa- } \\
\text { nies as current USD Di- } \\
\text { vided by the total popula- } \\
\text { tion of the country, }\end{array}$ \\
\hline $\begin{array}{lll}\text { Stock market development } \\
\text { indicators }\end{array}$ & Stock traded per capita & $\begin{array}{l}\text { Stock traded total value as } \\
\text { current USD divided by to- }\end{array}$ & WDI \\
& & $\begin{array}{l}\text { tal population. } \\
\text { The per capita gross do- } \\
\text { Economic output }\end{array}$ & WDI \\
\hline Population & GDP per capita & $\begin{array}{l}\text { People per sq. km of land } \\
\text { area }\end{array}$ & WDI \\
\hline Energy consumption & Population density & $\begin{array}{l}\text { Energy intensity level of } \\
\text { primary energy calculated } \\
\text { as units of energy per unit } \\
\text { of GDP. }\end{array}$ & \\
\hline
\end{tabular}


The evolution of carbon emission per capita $(C E P C)$ in all the emerging markets selected for this study over the period from 1995 to 2014 is presented in Figure 1. As may be seen in the plots, we can conclude that carbon emissions have increased remarkably since the 2000s especially for China, Korea, Malaysia, Thailand, Thailand, and Turkey. Also, we observe that the level of carbon emission is very high in Czech republic, Korea, Greece, Poland, and South Africa, and low in Pakistan, India, Philippines, Peru, Colombia, and Indonesia. However, we notice that Czech Republic, Greece, and Hungary have considerably reduced their carbon emissions level since they adopt a long-term plan of energetic policy.

The correlation matrix is a primary step towards establishing the nature of the relationship between the set of variables. Table 3 presents the correlation matrix of the variables used in this study. As noted in Kevin (1992), the likelihood of the presence of the problem of multicollinearity becomes high when the correlation coefficient between dependent and independent variables exceeds 0.7. As may be seen in Table 3, the coefficient of correlation between stock market development indicators and carbon emissions per capita $(C E P C)$ do not exceed 0.7, which suggests the absence of multicollinearity problem. However, the correlation coefficient between GDPPC and $\mathrm{CEPC}$ is 0.72 ; this indicates that these two variables are strongly positively correlated. High economic growth is strongly related to more carbon emission in emerging market economies.

Table 2: Summary statistics on individual and panel data set from 1995 to 2014

\begin{tabular}{|c|c|c|c|c|c|c|}
\hline Country & CEPC & EI & SMPC & STPC & GDPPC & PDPC \\
\hline Brazil & 1.972 & 3.920 & $6.28 \mathrm{e}+11$ & 1941.1 & 9873.4 & 22.014 \\
\hline Chile & 3.961 & 4.282 & $1.51 \mathrm{e}+11$ & 1334.9 & 11134.9 & 21.652 \\
\hline China & 4.6316 & 9.9732 & $2.49 \mathrm{e}+12$ & 2373.2 & 3073.93 & 137.88 \\
\hline Colombia & 1.5681 & 2.9293 & $1.46 \mathrm{e}+11$ & 241.72 & 5697.1 & 37.941 \\
\hline Czech Republic & 11.243 & 7.2635 & $2.73 \mathrm{e}+10$ & 1495.0 & 17283.9 & 133.76 \\
\hline Greece & 8.0291 & 3.8785 & $1.11 \mathrm{e}+11$ & 4697.7 & 24829.3 & 84.615 \\
\hline Hungary & 5.3773 & 5.3614 & $2.63 \mathrm{e}+10$ & 2046.3 & 11961.2 & 112.39 \\
\hline India & 1.1669 & 6.2035 & $9.93 \mathrm{e}+11$ & 640.83 & 1066.7 & 381.95 \\
\hline Indonesia & 1.5902 & 4.5757 & $1.59 \mathrm{e}+11$ & 209.87 & 2668.1 & 124.35 \\
\hline Korea & 9.9963 & 7.3865 & $5.95 \mathrm{e}+11$ & 19393.4 & 18177.1 & 496.56 \\
\hline Malaysia & 6.5529 & 5.3495 & $2.50 \mathrm{e}+11$ & 2798.8 & 8004.5 & 77.262 \\
\hline Mexico & 4.1293 & 4.2658 & $2.61 \mathrm{e}+11$ & 650.9 & 9127.4 & 54.366 \\
\hline Pakistan & 0.8176 & 5.1739 & $2.95 \mathrm{e}+10$ & 247.80 & 910.54 & 206.21 \\
\hline Peru & 1.3694 & 2.7445 & $4.11 \mathrm{e}+10$ & 115.22 & 4123.5 & 21.511 \\
\hline Philippines & 0.8961 & 4.0880 & $8.80 \mathrm{e}+10$ & 197.82 & 1863.2 & 285.9 \\
\hline Poland & 8.1815 & 6.316 & $9.22 \mathrm{e}+10$ & 925.76 & 10205.5 & 124.93 \\
\hline South Africa & 8.9092 & 10.159 & $5.14 \mathrm{e}+11$ & 2674.6 & 6632 & 39.379 \\
\hline Thailand & 3.5805 & 5.3209 & $1.58 \mathrm{e}+11$ & 1747.5 & 4307.8 & 126.67 \\
\hline Turkey & 3.6542 & 3.6615 & $1.38 \mathrm{e}+11$ & 2801.7 & 9610.4 & 87.648 \\
\hline \multicolumn{7}{|l|}{ Consolidated } \\
\hline Observation & 380 & 380 & 380 & 380 & 380 & 380 \\
\hline Mean & 4.6119 & 5.4134 & $3.63 \mathrm{e}+11$ & 2449.2 & 8450.0 & 135.63 \\
\hline Maximum & 12.365 & 14.228 & $6.00 \mathrm{e}+12$ & 39394.9 & 30054.9 & 520.85 \\
\hline Minimum & 0.68255 & 2.3419 & $4.56 \mathrm{e}+09$ & 2.7633 & 674.62 & 18.983 \\
\hline Std. dev & 3.3149 & 2.1629 & $7.23 \mathrm{e}+11$ & 5217.6 & 6450.1 & 124.87 \\
\hline
\end{tabular}

Note: CEPC: Per capita CO2 emissions in metric tons; EI: Energy intensity level of primary energy (MJ/\$2011 PPP GDP); SMPC: Market capitalization of listed domestic companies (current US\$)/total population; STPC: Stocks traded, total value (current US\$)/total population; GDPPC: GDP per capita (constant 2010 US\$); PDPC: Population density (people per sq. $\mathrm{km}$ of land area) 
Table 3: correlation matrix

\begin{tabular}{lllllll}
\hline & CEPC & EI & SMCPC & STPC & GDPPC & PDPC \\
\hline CEPC & 1.000 & & & & & \\
EI & 0.502 & 1.000 & & & & \\
SMCPC & 0.055 & 0.347 & 1.000 & & & \\
STPC & 0.475 & 0.159 & 0.229 & 1.000 & & \\
GDPPC & 0.724 & -0.059 & -0.113 & 0.508 & 1.000 & \\
PDPC & 0.092 & 0.246 & 0.173 & 0.492 & -0.012 & 1.000 \\
\hline
\end{tabular}

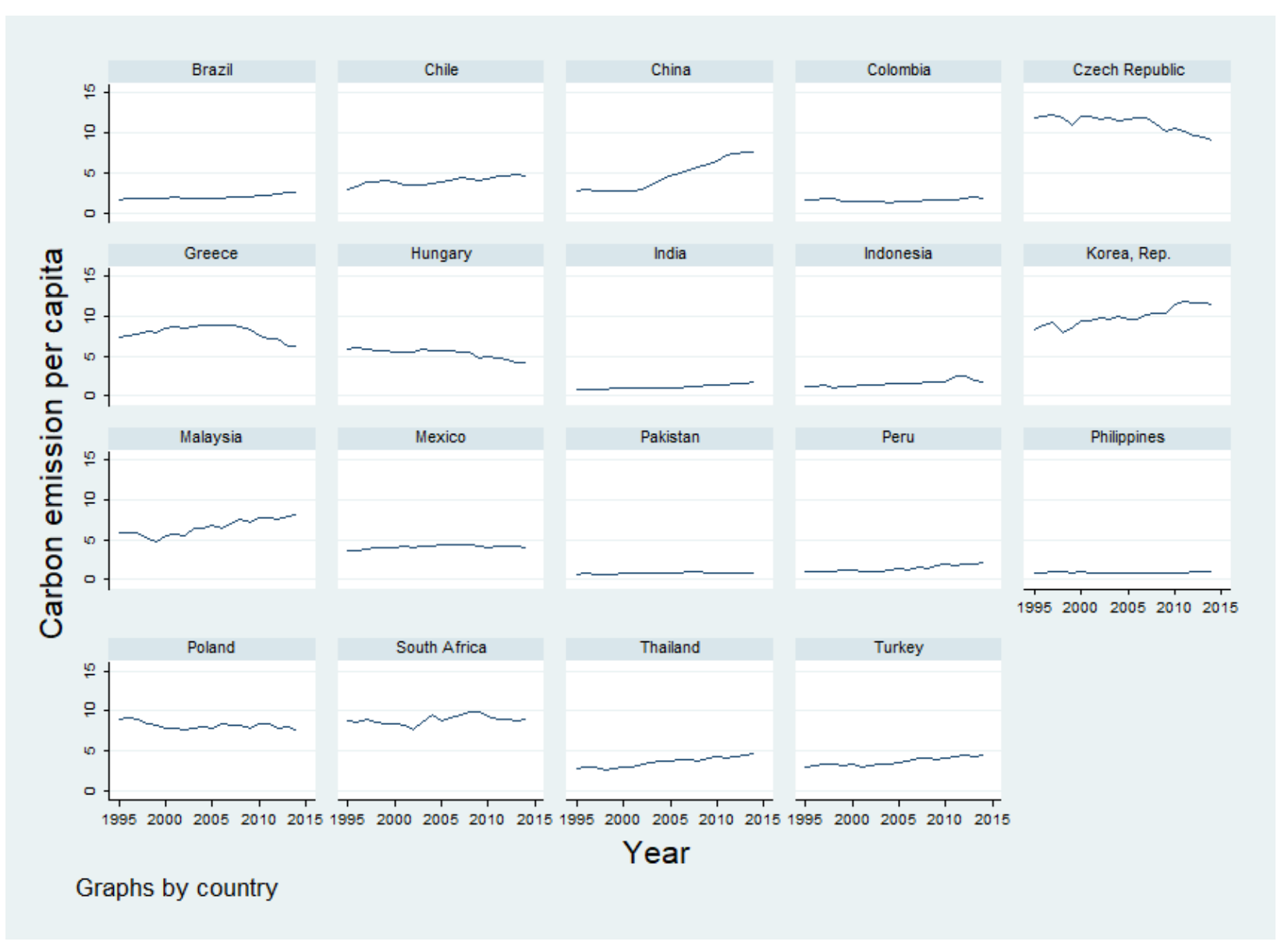

Figure 1: Plot of carbon emission per capita

The linear and non-linear ARDL methodology of cointegration is appropriate because it does not require that variables included in the model are I (0) or I (1). In order to ascertain the absence of I (2) variables in the model, it is mandatory to apply stationarity tests. We started our empirical analyses by examining the integration properties of all variables using four unit root tests as of Levin, Lin, and Chu (2002), a similar test is described by Harris and Tzavalis (1999), the Im, Pesaran, and Shin (2003) test, Fisher type test based on Dickey-Fuller and Philips-Perron. Table 3 show the results of unit root tests, which indicate the presence of unit root problems at level, but all underlying data becomes stationary at first difference for all variables. 


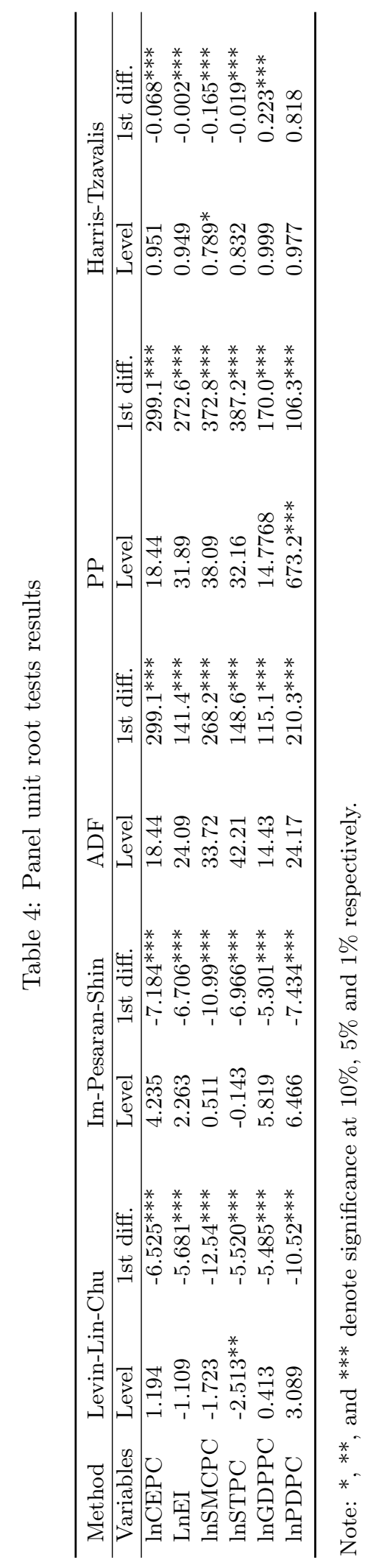




\subsection{Model specification}

As mentioned in the previous section, the main objective of this study is to examine both the symmetric and asymmetric relationship between stock market development, energy consumption and environmental quality. To accomplish this objective, we rely on the IPAT environmental model that was first proposed by (Ehrlich and Holdren, 1971). The fundamental form of the IPAT model may be described as follows:

$$
I=P \times A \times T
$$

Where $I, P, A$, and $T$ represent environmental quality or pollution, population, Affluence lever of a region, technology, or development level, respectively. Recently, the IPAT model has been extended by Dietz and Rosa $(1994,1997)$ in order to obtain a stochastic version. The new version is known as STIRPAT model (Stochastic impact by regression on population, affluence, and technology model). The STIRPAT model explains environmental quality in terms of three important determinants of $\mathrm{CO}_{2}$ emissions as population, economic output, and technology level in the country.

The variant of this model that we adopted for this study may be represented as follows:

$$
\ln I=\alpha+\beta \ln P+\delta \ln A+\lambda \ln T+\gamma \ln S+\varepsilon
$$

where $I$ represents per capita carbon emissions (metric ton per capita), $P$ represents population density (people per sq.km of land area). $A$ denotes affluence represents GDP per capita, $T$ explains energy intensity level of primary (quantity of energy required per unit of output), and $S$ represents stock market development measures (stock market capitalization and stock traded). As mentioned above, we developed a model using two different measures of stock market development (stock market capitalization and stock traded) following the study of Paramati et al (2018).

The functional form of Equation 2 may be written as follows:

$$
\ln C E P C_{i}=\beta_{0}+\beta_{1} \ln E I_{i, t}+\beta_{2} \ln S M D_{i, t}+\beta_{3} \ln G D P P C_{i, t}+\beta_{4} \ln P D P C_{i, t}+\varepsilon_{i, t}
$$

Where $C E P C$ represents per capita carbon emission, $E I$ represents energy intensity, $S M D$ is a stock market development indicators $(S M C P C$ means a per capita stock market capitalization and $S T P C$ is a stock traded per capita), GDPPC is a per capita gross domestic product, $P D P C$ represents population density per capita, and $\beta_{i}$ represents the long-run coefficients vectors. In the next sections, we develop this model into linear and nonlinear forms using ARDL and NARDL methodologies.

\subsubsection{The symmetric panel ARDL}

In this study, we are first interested in the symmetric response of stock market development to environmental quality. To achieve this particular aim, we apply the Auto-Regressive Distributed Lag model (ARDL) proposed by (Pesaran and Shin, 1998). This model enables us to estimate the cointegration relationship among stock market development indicators, energy use and carbon emission. The ARDL model may be stated as follows:

$$
\Delta y_{t}=\sum_{i=1}^{n} \beta_{i} \Delta y_{t-i}+\sum_{i=0}^{n} \delta_{i} \Delta x_{t+i}+\phi_{1} \Delta y_{t-1}+\phi_{2} \Delta x_{t-1}+\mu_{t}
$$

Based on the objective of this study which is to investigate the relationship between per capita stock market development variables, energy use, economic output, population density and per capita carbon emissions, the above ARDL model to modified as follows:

$$
\begin{aligned}
& \Delta \operatorname{lnCEPC}=\beta_{0}+\alpha_{1} C E P C_{t-1}+\alpha_{2} E I_{t-1}+\alpha_{3} S M D_{t-1}+\alpha_{4} G D P P C_{t-1}+\alpha_{5} P D P C_{t-1} \\
& +\sum_{j=0}^{p} \beta_{1 i} \Delta E I_{i t-j}+\sum_{j=0}^{p} \beta_{2 i} \Delta S M D_{i t-j}+\sum_{j=0}^{p} \beta_{3 i} \Delta G D P P C_{i t-j}+\sum_{j=0}^{p} \beta_{4 i} \Delta P D P C_{i t-j}+\epsilon_{i t}
\end{aligned}
$$


Where, $\sum_{j=0}^{p} \beta_{1 i}$ represents the short-run effect of Stock market development on carbon emission while $\alpha_{3}$ represents the long run effect of Stock market development on carbon emission. The error correction model of the above equation is represented as follow:

$$
\begin{array}{r}
\Delta \operatorname{lnCEPC}=\beta_{0}+\sum_{j=0}^{p} \beta_{1 i} \Delta E I_{i t-j}+\sum_{j=0}^{p} \beta_{2 i} \Delta S M D_{i t-j} \\
+\sum_{j=0}^{p} \beta_{3 i} \Delta G D P P C_{i t-j}+\sum_{j=0}^{p} \beta_{4 i} \Delta P D P C_{i t-j}+\theta_{i} E C T_{(}(t-1)+\epsilon_{i t}
\end{array}
$$

where $\theta_{i}$ denotes the long-run equilibrium speed of adjustment after the shock in the short-run.

\subsubsection{The asymmetric panel ARDL}

Several empirical studies have demonstrated the presence of asymmetries in the impact of stock market indicators on different dependent variables. In other words, positive and negative shocks on stock market indicators appear to have asymmetric effects on other variables. To investigate the presence of this phenomenon on the effects of stock market development indicators on carbon emissions, we rely on the Non-linear ARDL (NARDL) approach which allow us to examine both short- and long-run asymmetric responses of carbon emission to positive and negative shocks on stock market development. To examine this nonlinear relationship, we decompose changes in the exogenous variable (stock market development) into its positive and negative partial sums of increases and decreases, to examine their impact on the independent variable $\left(\mathrm{CO}_{2}\right.$ emission per capita).

Following the above, we rely on NARDL model proposed by Shin et al (2014). The NARDL may be stated as follows:

$$
\begin{aligned}
& \Delta \ln C E P C=\gamma_{0}+\vartheta_{1} \ln C E P C_{t-1}+\vartheta_{2} \ln E I_{t-1}+\vartheta_{3} \ln S M D_{t-1}^{+}+\vartheta_{4} \ln S M D_{t-1}^{-} \\
& +\vartheta_{5} \ln G D P P C_{t-1}+\vartheta_{6} \ln P D P C_{t-1}+\sum_{j=0}^{p} \delta_{1 i} \Delta \ln E I_{i t-j}+\sum_{j=0}^{p} \delta_{2 i} \Delta \ln S M D_{i t-j}^{+} \\
& +\sum_{j=0}^{p} \delta_{3 i} \Delta \ln S M D_{i t-j}^{-}+\sum_{j=0}^{p} \delta_{4 i} \Delta \ln G D P P C_{i t-j}+\sum_{j=0}^{p} \delta_{5 i} \Delta \ln P D P C_{i t-j}+\epsilon_{i t}
\end{aligned}
$$

where, $\sum_{j=0}^{p} \delta_{2 i}$ and $\sum_{j=0}^{p} \delta_{3 i}$ captures the short-run positive and negative effect of Stock market development on environmental quality while $\vartheta_{3}$ and $\vartheta_{4}$ captures the long-run effect stock market growth on carbon emission. Lastly, the error correction equation may be represented as follows:

$$
\begin{aligned}
\Delta \ln C E P C= & \gamma_{0}+\sum_{j=0}^{p} \delta_{1 i} \Delta \ln E I_{i t-j}+\sum_{j=0}^{p} \delta_{2 i} \Delta \ln S M D_{i t-j}^{+}+\sum_{j=0}^{p} \delta_{3 i} \Delta \ln S M D_{i t-j}^{-} \\
& +\sum_{j=0}^{p} \delta_{4 i} \Delta \ln G D P P C_{i t-j}+\sum_{j=0}^{p} \delta_{5 i} \Delta \ln P D P C_{i t-j}+\rho_{i} E C T_{t-1}+\epsilon_{i t}
\end{aligned}
$$

\subsection{Empirical results and discussion}

In this section, we present results from our analysis of the linear and nonlinear relationship between stock market development, energy use and carbon emission across the panel of 19 chosen emerging market economies. The discussion of these analyses are presented in the following subsections.

\subsubsection{Results from panel ARDL model}

In this section, we investigate both the short-run and the long-run linear impact, respectively, of stock market development indicators and energy efficiency on carbon emission across the panel of emerging market economies. As stated earlier, we transformed all the variables into their natural logarithms in order to interpret the estimated coefficients as elasticities. Table 5 presents the shortand long-run linear relationship as defined in Equation 5. As may be seen in Table 5, the short-run 
elasticities suggest that energy intensity has a positive and significant effect on carbon emission at the $1 \%$ level. This suggests that a $1 \%$ increase in energy use raises $\mathrm{CO}_{2}$ emission by $0.53 \%$. In addition, economic growth has a positive and significant impact with about $0.6 \%$ rise in carbon emission being explained by a $1 \%$ growth in GDP per capita. Regarding stock market indicators, the stock market capitalization appear not to be statistically significant while the volume of stock traded is negative but significant only at $10 \%$ level. Moreover, the long-run estimation results suggest that energy intensity has a significant and positive impact of about $0.8 \%$ improvement in carbon emission being explained by $1 \%$ improvement in energy use per unit of GDP. However, population density has a negative and significant impact in the long run at a $1 \%$ level, with a two-and-a-half-year adjustment range. Put differently, a $1 \%$ raise in per capita population density decreases per capita CO-2 emission by $2.14 \%$ and $0.68 \%$.

For stock market development indicators, the results of the linear long-run relationship have significant policy implications. Stock market capitalization becomes significant at a $1 \%$ level across all panel in the long-run. This implies that a $1 \%$ increase in stock market capitalization increases emissions by $0.02 \%$. Similarly, the long-run elasticities show that a $1 \%$ raise in stock traded increases $\mathrm{CO}_{2}$ emissions by $0.015 \%$. These results are in the line with previous studies such as Paramati et al (2017) and Zafar et al (2019) for emerging market countries. These findings show that stock market development has a negative impact on environmental quality in emerging market economies. This may be explained by the link between financial development, economic growth, energy use and carbon emissions. Financial development is generally accompanied by increased energy consumption and economic growth that contribute to carbon emissions because creating new sources of funds allows firms to extend their production, which contributes to energy use especially fossil fuel energy (see e.g. Lee and Chang, 2008; Sadorsky, 2010; Wan and Ayres, 2010; Ozturk,2010). Lastly, these observed negative relationships between stock market development indicators and environmental quality suggest that emerging market economies should implement environmentally-friendly policies to reduce carbon emission by maximizing their energy efficiency level.

Table 5: Linear ARDL estimations

\begin{tabular}{|c|c|c|c|}
\hline Variable & Model 1 & Variable & Model 2 \\
\hline $\mathrm{ECT}$ & $\begin{array}{l}-0.377^{* * *} \\
(0.081)\end{array}$ & $\mathrm{ECT}$ & $\begin{array}{l}-0.423^{* * *} \\
(0.079)\end{array}$ \\
\hline \multicolumn{4}{|c|}{ Short run relationship } \\
\hline D.lnEI & $\begin{array}{l}0.532^{* * *} \\
(0.136)\end{array}$ & D.lnEI & $\begin{array}{l}0.525^{* * *} \\
(0.141)\end{array}$ \\
\hline D.lnSMCPC & $\begin{array}{l}-0.002 \\
(0.008)\end{array}$ & D.lnSTPC & $\begin{array}{l}-0.009^{*} \\
(0.005)\end{array}$ \\
\hline D.lnGDPPC & $\begin{array}{l}0.602^{* * *} \\
(0.146)\end{array}$ & D.lnGDPPC & $\begin{array}{l}0.643^{* * *} \\
(0.141)\end{array}$ \\
\hline D.lnPDPC & $\begin{array}{l}-2.148 \\
(2.998)\end{array}$ & D.lnPDPC & $\begin{array}{l}-0.687 \\
(3.125)\end{array}$ \\
\hline \multicolumn{4}{|c|}{ Long run relationship } \\
\hline $\ln E I$ & $\begin{array}{l}0.809^{* * *} \\
(0.112)\end{array}$ & $\ln E I$ & $\begin{array}{l}0.740^{* * *} \\
(0.102)\end{array}$ \\
\hline $\operatorname{lnSMCPC}$ & $\begin{array}{l}0.028^{* * *} \\
(0.008)\end{array}$ & $\operatorname{lnSTPC}$ & $\begin{array}{l}0.0145^{* *} \\
(0.006)\end{array}$ \\
\hline $\operatorname{lnGDPPC}$ & $\begin{array}{l}1.285^{* * *} \\
(0.643)\end{array}$ & $\operatorname{lnGDPPC}$ & $\begin{array}{l}1.205^{* * *} \\
(0.0587)\end{array}$ \\
\hline $\operatorname{lnPDPC}$ & $\begin{array}{l}-0.929^{* * *} \\
(0.155)\end{array}$ & $\operatorname{lnPDPC}$ & $\begin{array}{l}-0.777^{* * *} \\
(0.132)\end{array}$ \\
\hline$c$ & $\begin{array}{l}-1.184^{* * *} \\
(0.282)\end{array}$ & $c$ & $\begin{array}{l}-1.289^{* * *} \\
(0.265)\end{array}$ \\
\hline Obs. & 361 & Obs. & 361 \\
\hline
\end{tabular}

Note: Number in parenthesis indicate standard errors. "***", "***" and "** indicate respectively significant value at $1 \%, 5 \%$ and $10 \%$. 


\subsubsection{Analyses of nonlinear relationship:}

Given that this study also aims to deepen the understanding of the asymmetric effects of stock market development in the level of environmental quality. In a bid to achieve this goal, we investigate the nonlinear relationship between stock market development indicators, energy efficiency and environment quality using the Nonlinear Auto-Regressive Distributed Lags (NARDL) approach. Table 6 reports the estimates from the nonlinear effects of stock market development on environmental quality across our chosen emerging market economies. As may be seen in Table 6, the short- and long-run elasticities suggest that energy intensity and economic growth have positive and significant relationship with carbon emissions at $1 \%$ level. In particular, about $0.53 \%$ increase in carbon emissions is due to a $1 \%$ raise in energy use. Also, population density has a significant negative impact on $\mathrm{CO}_{2}$ emission only in the long run. Specifically, results suggest that a $1 \%$ increase in PDPC decrease carbon emissions by $0.7 \%$. Taken together, the nonlinear results suggest that stock market development indicators have a diverse relationship with environmental quality, implying that the development of stock market have an asymmetric impact on environmental degradation in emerging market economies.

Moreover, the volume of stock traded per capita which reflects the level of liquidity in the stock market has a nonlinear impact on environmental quality. The short-run elasticities suggests that only positive shock has a negative and significant effect on emissions. This implies that a $1 \%$ evolution in STPC positive shock decreases carbon emission by $0.02 \%$ while in the long-run, a shock on STPC has a positive and significant impact at a $1 \%$ level on carbon emission. Also, the relationship between the positive and negative partial-sums of stock market capitalization and carbon emissions show that positive shocks in stock market have no significant impact on emissions in the short-run, while; negative shocks have a negative and significant impact on $\mathrm{CO}_{2}$ emission at a $10 \%$ level. Although, the long-run elasticities show both SMPC positive and negative shocks have a positive and very significant impact on environmental degradation. In other words, $1 \%$ evolution in positive and negative shocks of stock market capitalization increase respectively carbon emissions by $0.023 \%$ and $0.042 \%$. Lastly, these outcomes suggest that negative shocks on stock market capitalization has a greater impact on carbon emissions. A possible explanation to this is that when stock market capitalization increases, there seem to be fewer opportunities to finance green project and new technologies and thus, there will be recourse to the use of polluting fossil fuels.

\subsubsection{Panel granger causality results}

In this subsection, use Granger causality tests to identify the predictive power of a variable $\mathrm{X}$ for variable $\mathrm{Y}$. We say $\mathrm{X}$ granger causes $\mathrm{Y}$, if the past information in variable $\mathrm{X}$ yields better forecasts of $\mathrm{Y}$. In other words, if variable $\mathrm{X}$ granger causes variable $\mathrm{Y}$, repeated changes are observed in series $\mathrm{Y}$ after the changes in series $\mathrm{X}$, approximately. Indeed, compared to times series models, panel data models present some advantages for causal relationship test, because; first, they include more observations than individual time series. Second, they allow for modelling the cross-sectional behavior. In this study, we used Panel Granger causality technique to detect the predictability power that exists among the variables. To develop the policy implications, it is essential to know the two ways causal relationships between variables. In this way, we employ, in this study panel heterogeneous causality method provided by Dumitrescu and hurlin (2012). The related results are presented in Table 7. As we can notice in Table 7, the Granger causality results indicate that bidirectional causality runs between energy intensity, economic growth, population density and carbon emissions. Put differently, the connection between stock market development indicators and carbon emission is bidirectional, which is in the line with Zafar et al (2019). Meanwhile, the outcomes of nonlinear causality show that only negative changes in per capita stock market capitalization have a predictive power on $\mathrm{CO}_{2}$ emissions. This indicates that there exists an asymmetric causality relationship between stock market development and carbon emission. 
Table 6: Nonlinear ARDL estimations

\begin{tabular}{|c|c|c|c|}
\hline Variables & Model 1 & Variables & Model 2 \\
\hline ECT & $\begin{array}{l}-0.381^{* * *} \\
(0.081)\end{array}$ & ECT & $\begin{array}{l}-0.447^{* * *} \\
(0.099)\end{array}$ \\
\hline \multicolumn{4}{|c|}{ Short run relationship } \\
\hline D.lnEI & $\begin{array}{l}0.509 * * * \\
(0.142)\end{array}$ & D.lnEI & $\begin{array}{l}0.500^{* * *} \\
(0.154)\end{array}$ \\
\hline D.lnSMCPC + & $\begin{array}{l}0.013 \\
(0.019)\end{array}$ & D. $\operatorname{lnSTPC}{ }^{+}$ & $\begin{array}{l}-0.020^{*} \\
(0.011)\end{array}$ \\
\hline D. $\operatorname{lnSMCPC}{ }^{-}$ & $\begin{array}{c}-0.017^{*} \\
(0.009)\end{array}$ & D. $\operatorname{lnSTPC}{ }^{-}$ & $\begin{array}{l}0.001 \\
(0.007)\end{array}$ \\
\hline D.lnGDPPC & $\begin{array}{l}0.604^{* * *} \\
(0.146)\end{array}$ & D.lnGDPPC & $\begin{array}{l}0.618^{* * *} \\
(0.149)\end{array}$ \\
\hline D.lnPDPC & $\begin{array}{l}-1.626 \\
(3.026)\end{array}$ & D.lnPDPC & $\begin{array}{l}0.178 \\
(3.409) \\
\end{array}$ \\
\hline \multicolumn{4}{|c|}{ Long run relationship } \\
\hline $\operatorname{lnEI}$ & $\begin{array}{l}0.918^{* * *} \\
(0.120)\end{array}$ & $\ln E I$ & $\begin{array}{l}0.784^{* * *} \\
(0.079)\end{array}$ \\
\hline $\operatorname{lnSMCPC}{ }^{+}$ & $\begin{array}{l}0.024^{* *} \\
(0.013)\end{array}$ & $\operatorname{lnSTPC}{ }^{+}$ & $\begin{array}{l}0.036^{* * *} \\
(0.009)\end{array}$ \\
\hline $\operatorname{lnSMCPC}{ }^{-}$ & $\begin{array}{l}0.043^{* * *} * \\
(0.012)\end{array}$ & $\operatorname{lnSTPC}{ }^{-}$ & $\begin{array}{l}0.012 \\
(0.010)\end{array}$ \\
\hline $\operatorname{lnGDPPC}$ & $\begin{array}{l}1.288^{* * *} * \\
(0.075)\end{array}$ & $\operatorname{lnGDPPC}$ & $\begin{array}{l}1.001^{* * *} \\
(0.057)\end{array}$ \\
\hline $\operatorname{lnPDPC}$ & $\begin{array}{l}-0.667^{* * *} \\
(0.229)\end{array}$ & $\operatorname{lnPDPC}$ & $\begin{array}{l}-0.761^{* * *} \\
(0.177)\end{array}$ \\
\hline$c$ & $\begin{array}{l}-1.396^{* * *} \\
(0.319)\end{array}$ & $c$ & $\begin{array}{l}-1.073^{* * *} \\
(0.261)\end{array}$ \\
\hline Obs. & 361 & Obs. & 361 \\
\hline
\end{tabular}

Notes: Number in parenthesis indicate standard errors. ${ }^{* * *}, * *$ and $*$ indicate respectively significant value at $1 \%, 5 \%$ and $10 \%$.

Table 7: Panel granger causality results

\begin{tabular}{|c|c|c|c|}
\hline Null Hypothesis & $W$-stat. & $p$-value & Causality flow \\
\hline $\mathrm{EI} \rightarrow \mathrm{CEPC}$ & $2.916^{* * *}$ & $(0.0035)$ & \multirow[b]{2}{*}{$\mathrm{EI} \longleftrightarrow \mathrm{CEPC}$} \\
\hline $\mathrm{CEPC} \rightarrow \mathrm{EI}$ & $7.286^{* * *}$ & $(0.0000)$ & \\
\hline $\mathrm{SMPC} \rightarrow \mathrm{CEPC}$ & $3.269^{* * *}$ & $(0.0011)$ & \multirow[b]{2}{*}{$\mathrm{SMPC} \longleftrightarrow \mathrm{CEPC}$} \\
\hline $\mathrm{CEPC} \rightarrow \mathrm{SMPC}$ & $10.70^{* * *}$ & $(0.0000)$ & \\
\hline $\mathrm{STPC} \rightarrow \mathrm{CEPC}$ & $7.594^{* * *}$ & $(0.0000)$ & \multirow[b]{2}{*}{$\mathrm{STPC} \longleftrightarrow \mathrm{CEPC}$} \\
\hline $\mathrm{CEPC} \rightarrow \mathrm{STPC}$ & $5.538^{* * *}$ & $(0.0000)$ & \\
\hline $\mathrm{GDPPC} \rightarrow \mathrm{CEPC}$ & $5.074^{* * *}$ & $(0.0000)$ & \multirow[b]{2}{*}{$\mathrm{GDPPC} \longleftrightarrow \mathrm{CEPC}$} \\
\hline $\mathrm{CEPC} \rightarrow \mathrm{GDPPC}$ & $8.6676^{* * *}$ & $(0.0000)$ & \\
\hline $\mathrm{PDPC} \rightarrow \mathrm{CEPC}$ & $32.26^{* * *}$ & $(0.0000)$ & \multirow[b]{2}{*}{$\mathrm{PDPC} \longleftrightarrow \mathrm{CEPC}$} \\
\hline $\mathrm{PDPC} \rightarrow \mathrm{GDPPC}$ & $8.114^{* * *}$ & $(0.0000)$ & \\
\hline $\mathrm{SMPC}^{+} \rightarrow \mathrm{CEPC}$ & -0.4385 & $(0.6610)$ & $\mathrm{SMPC}^{+} \downarrow \mathrm{CEPC}$ \\
\hline $\mathrm{SMPC}^{-} \rightarrow \mathrm{CEPC}$ & $3.9095 * * *$ & $(0.0001)$ & $\mathrm{SMPC}^{-} \rightarrow \mathrm{CEPC}$ \\
\hline $\mathrm{STPC}^{+} \rightarrow \mathrm{CEPC}$ & $3.7275^{* * *}$ & $(0.0002)$ & $\mathrm{STPC}^{+} \rightarrow \mathrm{CEPC}$ \\
\hline $\mathrm{STPC}^{-} \rightarrow \mathrm{CEPC}$ & $2.8982^{* *}$ & $(0.0038)$ & $\mathrm{STPC}^{-} \rightarrow \mathrm{CEPC}$ \\
\hline
\end{tabular}

Note: ${ }^{* * *}$ significant value at $1 \% ;{ }^{* *}$ significant value at $5 \% ;{ }^{*}$ significant value at $10 \%$. 


\section{Conclusion and policy implications}

The relationship between stock market development, economic growth and energy use is well documented in the literature. However, there are only few studies that investigates the links between stock market development and environmental quality. Previous studies have demonstrated that the impact of stock market development on environment quality is positive in developed economies and negative impact in emerging market economies (see e.g. Paramati et al, 2017). Moreover, the empirical study of Zafar et al., (2020) suggest a positive relationship between industrialization and carbon emission. Nevertheless, It is not yet clear from previous studies whether positive and negative shocks on stock market development increase or decrease environmental degradation. In trying to bridge this knowledge gap in the literature, this study investigates both the symmetric and asymmetric impacts of stock market development, energy efficiency on environmental quality across a panel of 19 emerging market economies over the period from 1995 to 2014.

Results from the symmetric effects of stock market development on carbon emissions demonstrates that stock market development indicators hurt the environment in emerging market economies. This result is in consonance with the study of Paramati et al. (2017). However, the nonlinear estimation results suggest that both positive and negative shocks on stock market development have negative effects on environmental quality. The linear long-run elasticities show that stock market development in emerging economies increase carbon emissions because development stock market has the potential to attract funds to finance production and manufacturing activities that lead to increase in energy consumption, especially fossil fuel energy in countries with weak environmental regulations. Consequently, this leads to an increase in the level of carbon emissions. Considering results from the asymmetric model, the long-run elasticities reveal a new impact of stock market development indicators on environmental quality. The empirical findings show that negative shocks in stock market capitalization have a greater impact than positive shocks on carbon emissions in emerging market economies.

Given the above findings, our study provides some important policy implications for policy makers and investors in the emerging market economies. First, the implications of our findings suggests that although developed stock markets may provide sources of funds for the emerging markets, this may have a negative impact on environmental quality when environmental regulations on reducing emission is not strictly enforced in emerging countries. Secondly, positive shocks in stock market capitalization hurt the environment because when stock market is developed there are more sources to finance production and manufacturing which increase emissions by increasing pollutant energy consumption. However, negative shocks in stock market capitalization may also increase emissions. This may be expressed in negative changes in stock market capitalization that means less sources of funds to finance new technologies and renewable energy project which tend to promote the use of fossil fuel energy; there by increasing carbon emissions.

Taken together, these results suggest that the development of stock market as measured by stock market capitalization per capita in emerging market economies has a substantial negative impact on environmental quality. These demonstrate that stock market activities hurt the environment by increasing carbon emissions in emerging market countries. This implies that stock market policies that seek to enforce compliance to environmental regulations may not have been effective in emerging markets. Therefore, this study recommends that policy makers in these emerging economies should establish more environmentally friendly policies that will promote the transition to green technologies and renewable energy sources. 


\section{References}

1. Abbasi, F., Riaz, K. (2016). CO2 emissions and financial development in an emerging economy: An augmented VAR approach. Energy Policy, 90, 102-114.

2. Apergis, N., Gangopadhyay, P. (2020). The asymmetric relationships between pollution, energy use and oil prices in Vietnam: Some behavioural implications for energy policy-making. Energy Policy, 140, 111430.

3. Balcilar, M., Demirer, R., Hammoudeh, S. (2019). Quantile relationship between oil and stock returns: Evidence from emerging and frontier stock markets. Energy Policy, 134, 110931.

4. Bartleet, M., Gounder, R. (2010). Energy consumption and economic growth in New Zealand: Results of trivariate and multivariate models. Energy Policy, 38(7), 3508-3517.

5. Baz, K., Xu, D., Ali, H., Ali, I., Khan, I., Khan, M. M., Cheng, J. (2020). Asymmetric impact of energy consumption and economic growth on ecological footprint: Using asymmetric and nonlinear approach. Science of The Total Environment, 137364.

6. Bhattacharya, M., Paramati, S. R., Ozturk, I., Bhattacharya, S. (2016). The effect of renewable energy consumption on economic growth: Evidence from top 38 countries. Applied Energy, 162, $733-741$.

7. Chang, S.-C. (2015). Effects of financial developments and income on energy consumption. International Review of Economics Finance, 35, 28-44.

8. Demena, B. A., Afesorgbor, S. K. (2019). The effect of FDI on environmental emissions: Evidence from a meta-analysis. Energy Policy, 111192.

9. Dietz, T., Rosa, E.A., 1994. Rethinking the environmental impacts of population, affluence and technology. Human ecology review 1, 277-300.

10. Dietz, T., Rosa, E.A., 1997. Effects of population and affluence on CO2 emissions. The national academy of sciences of the USA 94, 175-179

11. Dumitrescu, E.-I., Hurlin, C. (2012). Testing for Granger non-causality in heterogeneous panels. Economic Modelling, 29(4), 1450-1460.

12. Ehrlich, P.R., Holdren, J.P., 1971. Impact of Population Growth. Science 171, 1212-1217 13.

Escobari, D., Sharma, S. (2020). Explaining the nonlinear response of stock markets to oil price shocks. Energy, 213, 118778.

14. Fan, W., Hao, Y. (2019). An empirical research on the relationship amongst renewable energy consumption, economic growth and foreign direct investment in China. Renewable Energy.

15. Gaies, B., Kaabia, O., Ayadi, R., Guesmi, K., Abid, I. (2019). Financial development and energy consumption: Is the MENA region different? Energy Policy, 135, 111000.

16. Georgescu-Roegen, N. (1975). Dynamic models and economic growth. World Development, 3(11-12), 765-783.

17. Haug, A. A., Ucal, M. (2019). The Role of Trade and FDI for CO2 Emissions in Turkey: Nonlinear Relationships. Energy Economics.

18. Lanoie, P., Laplante, B., Roy, M. (1998). Can capital markets create incentives for pollution control ? Ecological Economics, 26(1), 31-41.

19. Lermit, J., Jollands, N., 2001. Key influences on energy efficiency trends in New Zealand: decomposition of energy to GDP ratio, 1987-2000. Energy-Wise Monitoring Quarterly 17, 3-20.

20. Lin, B., Benjamin, I. N. (2018). Causal relationships between energy consumption, foreign direct investment and economic growth for MINT: Evidence from panel dynamic ordinary least square models. Journal of Cleaner Production, 197, 708-720.

21. Mahdi Ziaei, S. (2015). Effects of financial development indicators on energy consumption and $\mathrm{CO} 2$ emission of European, East Asian and Oceania countries. Renewable and Sustainable Energy Reviews, 42, 752-759.

22. Muhammad, B., Khan, S. (2019). Effect of bilateral FDI, energy consumption, CO2 emission and capital on economic growth of Asia countries. Energy Reports, 5, 1305-1315.

23. Nusair, S. A. (2016). The effects of oil price shocks on the economies of the Gulf Co-operation Council countries: Nonlinear analysis. Energy Policy, 91, 256-267.

24. Ozturk, I., Acaravc1, A., 2010. CO2 emissions, energy consumption and economic growth in Turkey. Renew. Sust. Energ. Rev. 14, 3220-3225.

25. Paramati, S. R., Mo, D., Gupta, R. (2017). The effects of stock market growth and renewable energy use on CO 2 emissions: Evidence from G20 countries. Energy Economics, 66, 360-371.

26. Paramati, S. R., Ummalla, M., Apergis, N. (2016). The effect of foreign direct investment and stock market growth on clean energy use across a panel of emerging market economies. Energy 
Economics, 56, 29-41.

27. Qamruzzaman, M., Jianguo, W. (2020). The asymmetric relationship between financial development, trade openness, foreign capital flows, and renewable energy consumption: Fresh evidence from panel NARDL investigation. Renewable Energy.

28. Razmi, S. F., Ramezanian, B., Behname, M., Salari, T. E., Javad Razmi, S. M. (2019). The relationship of renewable energy consumption to stock market development and economic growth in Iran. Renewable Energy.

29. Sadorsky, P. (2010). The impact of financial development on energy consumption in emerging economies. Energy Policy, 38(5), 2528-2535.

30. Sadorsky, P. (2011). Financial development and energy consumption in Central and Eastern European frontier economies. Energy Policy, 39(2), 999-1006.

31. Salim, R. A., Rafiq, S. (2012). Why do some emerging economies proactively accelerate the adoption of renewable energy? Energy Economics, 34(4), 1051-1057.

32. Seker, F., Ertugrul, H. M., Cetin, M. (2015). The impact of foreign direct investment on environmental quality: A bounds testing and causality analysis for Turkey. Renewable and Sustainable Energy Reviews, 52, 347-356.

33. Shahbaz, M., Hye, Q. M. A., Tiwari, A. K., Leitão, N. C. (2013). Economic growth, energy consumption, financial development, international trade and CO2 emissions in Indonesia. Renewable and Sustainable Energy Reviews, 25, 109-121.

34. Tuna, G., Tuna, V. E. (2019). The asymmetric causal relationship between renewable and NON-RENEWABLE energy consumption and economic growth in the ASEAN-5 countries. Resources Policy, 62, 114-124.

35. Ullah, A., Xinshun, Z., Kamal, M. A., JiaJia, Z. (2020). Modeling the relationship between military spending and stock market development (a) symmetrically in China: An empirical analysis via the NARDL approach.

36. Ulusoy, V., Demiralay, S. (2017). Energy demand and stock market development in OECD countries: A panel data analysis. Renewable and Sustainable Energy.

37. United Nations (2015). Transforming our world: the 2030 Agenda for Sustainable Development, United Nations, New York.

Available at https://sustainabledevelopment.un.org/post2015/transformingourworld (accessed February 07,2021$)$.

38. Wen, F., Zhao, L., He, S., Yang, G. (2020). Asymmetric relationship between carbon emission trading market and stock market: Evidences from China. Energy Economics, 104850.

39. World Bank, 2016. World Development Indicators 2016. Washington DC. Available at: http://data.worldbank.org/data-catalog/world-development-indicators/.

40. Xu, W., Ma, F., Chen, W., Zhang, B. (2019). Asymmetric volatility spillovers between oil and stock markets: Evidence from China and the United States, Energy Economics, 80, 310-320.

41. Xu, Y. (2020). Will energy transitions impact financial systems? Energy, 116910.

42. Yue, S., Lu, R., Shen, Y., Chen, H. (2019). How does financial development affect energy consumption? Evidence from 21 transitional countries. Energy Policy, 130, 253-262.

43. Yue, S., Lu, R., Shen, Y., Chen, H. (2019). How does financial development affect energy consumption? Evidence from 21 transitional countries. Energy Policy, 130, 253-262.

44. Zafar, M. W., Qin, Q., malik, M. N., Zaidi, S. A. H. (2020). Foreign direct investment and education as determinants of environmental quality: The importance of post Paris Agreement (COP21). Journal of Environmental Management, 270, 110827.

45. Zafar, M. W., Shahbaz, M., Sinha, A., Sengupta, T., Qin, Q. (2020). How renewable energy consumption contribute to environmental quality? The role of education in OECD countries. Journal of Cleaner Production, 122149.

46. Zafar, M. W., Zaidi, S. A. H., Sinha, A., Gedikli, A., Hou, F. (2019). The role of stock market and banking sector development, and renewable energy consumption in carbon emissions: Insights from G-7 and N-11 countries. Resources Policy, 62, 427-436.

47. Zhang, D. (2008). Oil shock and economic growth in Japan: A nonlinear approach. Energy Economics, 30(5), 2374-2390. 